\title{
Against the tide: psychodynamic approaches to agitated childhood in France, between crisis and resistance
}

\section{À contre-courant: les approches psychodynamiques de l'enfance agitée en France, entre crise et résistance}

\author{
Céline Borelle \\ (D) https://orcid.org/0000-000I-9945-7075 \\ E-mail: celine.borelleœorange.com \\ Jean-Sébastien Eideliman ${ }^{b}$ \\ (D) https://orcid.org/0000-0001-9533-676X \\ E-mail: jean-sebastien.eidelimanळparisdescartes.fr \\ Maïa Fanstenc \\ (iD) https://orcid.org/0000-0002-6980-0319 \\ E-mail: maia.fanstenळparisdescartes. fr \\ Maëlle Planche ${ }^{c}$ \\ (iD) https://orcid.org/0000-0003-1806-8532 \\ E-mail: maelle.plancheळlaposte.net

\section{Amélie Turlais $^{\mathrm{d}}$} \\ (iD) https://orcid.org/0000-0002-6235-9831 \\ E-mail: amelieltæyahoo.co.uk \\ aOrange Labs. Département de Recherche en Sciences Sociales. \\ Paris, France. \\ bUniversité Paris Descartes. Centre de Recherche sur les Liens \\ Sociaux. Paris, France. \\ 'Université Paris Descartes. Centre de Recherche Médecine, \\ Sciences, Santé, Santé Mentale, Société. Paris, France. \\ dUniversité Paris $X$ Nanterre. Nanterre, France.
}

\section{Abstract}

Is psychoanalysis in crisis? This theme turned out to be recurrent in the comments of professionals working with a psychoanalytical orientation that we encountered during a collective survey on the trajectories of children considered as agitated in France. During this research, we conducted interviews with children and their families, with professionals working in care centres, schools and public administration; we also conducted observations and collected data in care centres. In these places, we observed a diversity of practices, but a clear majority of which claimed to be more or less strictly psychoanalytical or more broadly psychodynamic approaches. After presenting some principles that underlie the psychodynamic approach of agitation, the article discusses the crisis feeling expressed by the professionals met and the reasons that may have caused it. A detour through a reflective analysis of our investigative relationships helps to shed more light on the consequences of this climate on daily work in general and on relations with institutional partners in particular.

Keywords: Childhood; Care Centres; Psychoanalysis; Behavioural Disorders; Ethnography.

\section{Correspondence}




\section{Résumé}

La psychanalyse est-elle en crise ? Ce thème s'est avéré récurrent dans les propos des professionnels travaillant selon une orientation psychanalytique que nous avons croisés lors d'une enquête collective sur les trajectoires des enfants considérés comme agités en France. Durant cette recherche, nous avons mené des entretiens avec des enfants et leur entourage, avec des professionnels travaillant dans des centres de soin, des écoles et des Maisons départementales des personnes handicapées ; nous avons également conduit des observations et recueilli des données dans des centres de soin. Dans ces lieux, nous avons observé une diversité de pratiques, mais dont une nette majorité se revendiquait de manière plus ou moins stricte de la psychanalyse, ou plus largement d'approches psychodynamiques. Après avoir présenté quelques principes qui fondent l'approche psychodynamique de l'agitation, l'article revient sur le sentiment de crise que manifestent les professionnels rencontrés et sur les raisons qui peuvent en être à l'origine. Un détour par une analyse réflexive de nos relations d'enquête permet de mieux mettre en lumière les conséquences de ce climat sur le travail quotidien en général et sur les relations avec les partenaires institutionnels en particulier.

Mots-clés: Enfance; Centres de Soin; Psychanalyse; Troubles du Comportement; Ethnographie.

\section{Introduction}

The notion of crisis is one of those polysemous concepts that have spread to many sectors through their ability to represent a set of heterogeneous situations and feelings ${ }^{1}$. Economic crisis, social crisis, crisis of the family institution, crisis of democracy but also crisis of adolescence, crisis of anger, marital crisis or identity crisis: there are few sectors and individuals that that at some point do not experience crisis, or at least do not claim to be experiencing or to have experienced it. In the social sciences, the term crisis is also widely used to describe a set of equally disparate phenomena, from the Crisis of the Welfare State (Rosanvallon, 1981) to the Crisis of the Suburbs (Stébé, 1999) to the Crisis of the Social Bond (Farrugia, 1993). Very often, analyses that take the word seriously go back to its etymology, which refers to the critical decisions that certain situations demand. Crisis is then thought of as a moment of disorder that precedes a new order. Michel Dobry (1986) goes further in Sociology of Political Crises, by showing that the characteristic of real crises is that they simultaneously affect several social spheres of the same society. In other words, they produce a new articulation between previously disconnected spheres, before a new arrangement allows the return to an independent functioning of these spheres.

Is psychoanalysis also in crisis? According to those who practice it, yes, there is no doubt about it, even if this is not a new concern. The theme of crisis was recurrent in the comments of professionals working with a psychoanalytical orientation, whom we met during our collective survey on the pathways of children considered to be agitated. During this research, we interviewed children and their families (77 interviews with 59 different families), as well as professionals working in care centers (45 interviews), schools ( 21 interviews) and homes for the disabled (12 interviews). We also

\footnotetext{
1 We would like to thank the Pfizer Foundation and the IReSP, which made it possible for this research to be born and to continue for four years. We also thank all the participants in the SAGE (Les sens de l'agitation chez l'enfant - Meanings of Agitation among Children) research project at the University of Paris Descartes and the University of Lille 3. We are furthermore grateful to the people who listened to us, advised us and criticized us in a constructive way, in particular Isabelle Coutant, Isabelle Ville and Nicolas Dodier. We would like of course to thank all those who agreed to meet with us and share their experiences with us during our field surveys. Finally, we would like to express our special thanks to our translator, Liz Libbrecht.
} 
conducted observations and collected data in care centers (more than 300 observations of meetings, consultations and therapeutic workshops; creation of a database including more than 8 oo situations). In the care settings studied, we conducted surveys using interviews, often participating in observations and data collection. Thus, a team of researchers spent a total of four years participating, sometimes jointly but mainly alternately, in staff meetings and therapeutic groups, for an average of one and a half days per week (at the day care hospital in the southern districts of Paris referred to below); one researcher spent two years in several care institutions in the same Paris district, for an average of two days per week: observation of meetings, participation in therapeutic groups, observation of consultations (in the northern districts of Paris); and one researcher spent a year in several care institutions in a district of a city located in the Nord department, and observed a large number of meetings and care situations (mental health center in northern France). Other care institutions, not described in this article, were investigated by other researchers during the collective survey and will be the subject of other publications, even if they feed more diffusely into the reflection presented here.

While we observed a diversity of practices in these care institutions, a clear majority claimed to adhere to a greater or lesser degree to strictly psychoanalytical or, more broadly, psychodynamic ${ }^{2}$ approaches. The so-called psychodynamic approaches themselves encompass a diversity of techniques related to psychoanalysis, ranging from classical psychoanalytic treatment to long or short psychotherapies, for adults or children. With children, psychotherapy necessarily takes a particular turn: mediation generally involves drawing or playing, the therapist allows him-/herself more to emphasize and analyze the transfer ${ }^{3}$, and the duration of the psychotherapy is generally shorter (a few weeks) than in the case of conventional therapy (which can last several years). In all cases, these approaches are characterized by the reference underlying psychoanalytical theory, enabling the subject to obtain insights and/or achieve a personality change, and using techniques that emphasizing the work of interpretation and analysis of the transfer (Canceil et al., 2004).

The health centers that we studied $\left(\mathrm{CMP}^{4}\right.$, day hospitals, etc.) fall within the realm of public psychiatry and therefore receive a wide variety of patients, in terms both of symptoms and of social conditions. In this context, professionals who practice psychodynamic approaches are particularly defensive. This may come as a surprise, as they remain in the majority, especially in so-called sectorbased institutions. The creation of this psychiatric "sector", in March 1960, and especially its revival in the early 1970s (Henckes, 2015), took place in a context where psychoanalysis had a central place in psychiatry, and specifically in child and adolescent psychiatry. Almost 6o years later, its influence has been significantly eroded, but it is more deeply entrenched in France than elsewhere (Fansten, 2018).

Our intention here is not to rule on the supposed decline of psychoanalysis. Instead, we will examine this feeling of crisis, to understand what it encompasses and what it reveals. Admittedly, through our survey on the backgrounds of children considered to be agitated we met only some professionals using psychodynamic approaches in very specific conditions, which does not allow for a general overview of their situation or even their impressions. But it does provide us with information on some profound transformations in the field of support for these children. We will therefore seek to understand the reasons for this sense of crisis, the modalities that this defensive discourse can take, and its consequences on the ways of working with children and various partners. In particular, we

\footnotetext{
2 Psychoanalytically-inspired child psychiatry has been the dominant trend for many decades in France and psychoanalysis still has a significant weight in mental health institutions, such as in a number of CMPPs or CMPs (Fansten, 2018).

3 Transfer is a major concept in psychoanalysis. It refers to the process whereby unconscious desires are actualized and repeated in the therapeutic relationship. For example, the patient unconsciously puts the therapist in a parental position and plays back situations in therapy that seem to concern the therapist but actually relate to these family scenes and affects. Compared to other forms of psychotherapy, psychoanalysis is distinguished by the fact that transfer and its interpretation are an essential instrument of healing.

4 Medical-Psychological Centres (CMP) are public consultation and outpatient treatment structures attached to child psychiatry hospitals.
} 
will show that these professional positions can be linked to more general social processes with which they resonate.

We will begin by presenting some of the main principles that underlie the psychodynamic approach in the care of children with symptoms of agitation. We will then come back to the feeling of crisis expressed by the professionals we met, and the possible origins thereof. We will then take a detour through a reflexive analysis of our investigative relationships, before highlighting the consequences of this climate on daily work in general and relations with institutional partners in particular.

\section{Infantile agitation, disorder or symptom?}

One of the first characteristics of the psychoanalytical approach to agitation compared to cognitive-behavioral approaches and in particular those that recognize the existence of ADHD syndrome (attention deficit disorder with or without hyperactivity), is that it considers agitation as a symptom, that is, as the manifestation of psychological problems and conflicts that need to be clarified and worked on directly. Simply dealing with superficial and symptomatic effects is therefore perceived as pointless (since it does not tackle the real problems that sooner or later will cause other more or less troublesome symptoms), even harmful, since the symptom that could lead us to the underlying conflict or disorder is eliminated. In an informal discussion, Etienne, a psychomotor therapist at a mental health center in northern France, compared the diagnosis of ADHD to saying "I have a fever". He commented: "agitation is not a pathology, it's a symptom”.

In support of this framework of interpretation, the professionals we met frequently pointed out the fact that children in care are not agitated everywhere, in all their life contexts. According to them, this shows that agitation is not linked to an irrepressible tendency towards disorderly movement, but rather a defensive reaction to certain disturbing situations related to the psychological and social history of the child. They noted that the boundary between these two dimensions is sometimes difficult for professionals to draw (Borelle, 2017).

In this approach, the fact that agitation can be greatly reduced by the use of methylphenidatebased $^{5}$ drugs means that the drug only makes the symptom disappear, but leaves the child's problem intact. These professionals argue that since relational problems are complex to disentangle and characterize, they can easily be confused with other problems, leading to diagnostic errors, especially if the diagnosis relies on the apparent but misleading efficacy of molecules such as methylphenidate. Based on this reasoning, the administration of medication tends to focus the problem only on the child and thus ignores the family dynamics in which this symptom is embedded and to which it responds.

But a psychoanalytical approach does not mean a systematic refusal of drug treatment. As we witnessed in a CMP located in the northern districts of Paris, different approaches may coexist around an essentially psychodynamic theoretical framework. Drugs are used in a particular way: they are seen as a first step, consisting in both "calming the child" and "calming down the school", to allow for a possible second step consisting of care based on psychodynamic approaches. For instance, 9-year-old Pierre, a diabetic who was very agitated, had been on Ritalin for a few weeks when we meet him during an observation. He was treated by the head child psychiatrist, who described him in a meeting as a "distractible" child, who "searches for boundaries". She wondered about Pierre's father, whom she described as "distant from his son but paradoxically opposed to the idea of putting him in boarding school". She noted that Pierre was in high demand from his father and found it positive that he was able to "talk a little". This is why she considered setting up therapeutic care and shiatsu sessions, and continuing the treatment with Ritalin for the time being.

While drugs may, in some places and cases, be considered in addition to care, the key instrument

5 Like Ritalin, Quazym, or Concerta. The efficacy of methylphenidate is itself a validation criterion for the diagnosis of ADHD. 
of care remains speech. This is designed to be effective on several levels: caregivers are first of all responsible for putting into words the children's behaviors, affects and impulses, in order to produce the crucial "insight" in psychotherapy. This use of words be the caregiver must, in the more or less short term, trigger a use of words by the child him- or herself, which is supposed to partly replace certain "acting out", that is, a use of potentially violent gestures to express the unspeakable. Finally, the collective development of the meaning to be given to children's behaviors, which takes place in team meetings (the "syntheses" or "retakes"), equips caregivers by modifying their view of the child, or even the emotions they experience faced with him or her (the "counter-transference").

For instance, in a day hospital located in the southern districts of Paris, which receives restless children, mostly from unstable families, usually two half-days a week, the children are cared for in "therapeutic groups". In these groups of three or four individuals, they exchange ideas around a "mediation", which can be a game (Lego, Playmobil), an artistic activity (drawing, music, video), a sports activity (football, basketball), or even the reading of stories. These mediations are designed to be therapeutic moments that the caregivers discuss in teams (briefly during debriefings or at greater length during the weekly synthesis), and then use to collectively elicit the meaning to be given to interactions with children. This shifts their affects and their interpretations accordingly, as well as their behavior towards the children during the following sessions. Sometimes, as one of the psychologists in the meeting says, it is a question of "transforming spitting into a representation", that is, understanding that the spitting in question is not a personal attack on a caregiver, but a way of questioning the relationship with the adult. It is a form of pre-language, which will become language once the link is considered reliable and the child's impulsive and defensive behaviors have been calmed. To help the children gradually adopt interpretations that they could then make their own, caregivers often use a language process consisting in exchanging with one another possible interpretations of the child's behavior, in the child's presence. This is one of the reasons why there are always several caregivers with the children, most of the time in pairs, but sometimes many more, such as during tea breaks. This serves as a welcome moment for "evening" groups attended by children aged 6 to 14. Here is a typical example of one of these interactions, noted during a tea break where we were present:

- Caregiver 1: "He looks angry, Stéphane!"

- Caregiver 2: "Yes, but it's most probably because yesterday we had a meeting with his school and his teacher's not very happy with him.”

- Caregiver 1: "Oh, you think that's why?"

- The child: "Oh shut up! No, it's not that."

This approach, consisting in letting symptoms be expressed, with the idea that their expression is the foundation of the healing process, or at least of the path to "getting better" (Demailly; Garnoussi, 2017), encounters many difficulties as soon as it becomes conscious and controlled by language. These difficulties are highlighted by the school which, faced with such behavior, has to deal with disciplinary matters that fall outside of what it considers to be its main mission, and that prevent it from functioning properly. There are also difficulties related to the fact that psychodynamic approaches are called into question. They have been challenged by virulent criticism for several decades, and by competition from techniques that appear to be more scientific and more effective in the short term. Within this context, a sense of crisis is also developing among professionals whose work is grounded within a psychoanalytical approach.

\section{Crisis and sense of crisis}

This sense of crisis is sometimes expressed explicitly in meetings, in view of the growing credibility, within public opinion, patients' and parents' organizations, and health services, of competing approaches, particularly cognitivebehavioral approaches. For example, in a CMP in northern France, a psychologist commented during a meeting: 
Child psychiatry is under threat, we're increasingly being called into question. There's no more psyche, there's only the neurocognitive dimension. It started with autism, then it was hyperactivity, and then all the dys as well. Psychoanalysis is being challenged as never before. On the forums, parents can no longer say they're happy with the day hospital; if they do they're put down. They must be given the choice of care! It's like the documentary "Hugo's Brain", it's caricatural and misleading. I mean, it's related to what's happening in Lille 3, it's a disaster. Vinca Rivierre is the death of psychoanalysis. In short, the day hospital is presented as a place where parents are left in a closed airlock. We take their child away from them, they don't know what's being done.

Here the psychologist summarizes a number of difficulties that psychoanalysis is currently facing. On the one hand, the opposition between cognitivebehavioralism and psychoanalysis has tormented the psychoanalytical community for several decades and has crystallized around the case of autism, calling into question the "jurisdiction" (Abbott, 1988) of psychoanalysis. Autistic disorders, together with behavioral disorders (Coutant, 2012), are the two areas where psychoanalysts have felt deprived of their "license" (Hughes, 1996), and have seen the imposition of a framework of analysis which bundles together - behind notions that they consider to be "catch-alls" - a large number of situations previously referred to in more specific terms (dysharmony, infantile psychosis, developmental disorders, hyperkinesis, personality disorders, borderline personality etc.). On the other hand, the rise of parent organizations in the definition of health policies (Chamak, 2008; Crossley, 2006) has favored cognitive-behavioral approaches, which are more likely to establish parents and their organizations as partners, even under conditions. In this context, the parents' demands not to be left out, with little or no information on the therapeutic processes implemented to treat their children, are more audible. They reinforce criticism against psychoanalysis, which is accused of inducing a feeling of guilt and of excluding parents.

An additional indication of this sense of crisis can be seen in the differences between the vocabulary used in internal meetings and in events organized by the teams for a wider audience. The term psychoanalysis (and related terms, such as psychoanalytical) is more commonly used internally, while other terms are preferred externally, such as "psychodynamics" or "institutional psychotherapy", which refer outside the specialized arenas to vaguer and less connoted sets of approaches. The feeling of crisis is therefore rooted in a reality that, since the late 1990 s, has seen a weakening of psychoanalysis, including from within the field of mental health where it had long prevailed ${ }^{8}$. This weakening is manifested on different levels: intellectual, scientific, legislative and societal.

Psychoanalysis has seen its hegemony and authority “degraded" in recent times (Lézé, 2010) by regulations concerning the title of psychotherapist (Fansten, 2006), the rise of "evidence-based psychiatry” (Dodier; Rabeharisoa, 2006) along with the imperative of "therapeutic effectiveness" (Le Moigne, 2008), and the rise of neuroscience and the figure of the "brain subject" (Ehrenberg, 2004) or "brainhood" (Vidal, 2009). Cognitive-behavioral approaches, as we have seen, have benefited from the new context gradually introduced by the combination of parent organizations - to which the Internet has given an unprecedented voice in recent decades (Akrich; Meadel, 2007) -, transformations in international psychiatry since the publication in 1980

6 "Le cerveau d'Hugo" is a French documentary-fiction film directed by Sophie Révil in 2012, which presents in a fictional way the life of an autistic person since childhood, using testimonies from people with autism. It presents autism from the now dominant perspectives, giving an important place to a biological etiology.

7 Vinca Rivière is Professor of Psychology at the University of Lille and researcher in developmental psychology. In particular, she has created training and services enabling autistic children to follow behavioral treatments, through the non-profit organization Pas à Pas, which she also founded.

8 Attacks against psychoanalysis also existed long before, but they took place in a context of the expansion and authority of psychoanalysis, in psychiatry as well as in the French intellectual and cultural landscape (Fansten, 2018). 
of the DSM III ${ }^{9}$ (Demazeux, 2013), and the evolution of the place and role given to patients and their relatives, with in particular the law of 4 March 2002 on patients' rights and the quality of the health system.

At the same time, changes in the medico-social field in general and disability policies in particular have spawned new challenges to psychodynamic approaches. First structured by the 1975 laws, which created commissions to recognize, guide and empower people with disabilities (Tricart, 1981), the field of disability was further consolidated and even expanded with the 2005 law on equal rights and opportunities, participation and citizenship for people with disabilities. This law gave the first legal definition of disability, including possible new origins, in particular psychological and cognitive alterations. In 2005, psychiatrists, who had mostly been hostile to the concept of disability since the 1970s (Castel, 1983), were more favorable to the notion of psychological disability promoted by organizations of mentally ill people, such as the UNAFAM and the FNAP-Psy (Chapireau, 2014). Psychoanalysts, including those who were psychiatrists, were however overwhelmingly hostile to this new concept, which they believed enshrined the idea that mental illnesses were unlikely to change, and encouraged individuals to integrate this idea in return for the validation of a number of material and financial rights. In practice, the medico-social field relies heavily on medical expertise and builds its networks locally so that psychiatrists are more or less directly involved in the examination of disability application files in the case of mental health problems (Borelle, 2014). This collaboration, which is essentially structured around medical diagnosis, is once again favoring those who are more willing to make and to communicate diagnoses, which is different on two counts from the usual practices of professionals who have a psychoanalytical approach.
Finally, the evolution of public policies in the field of health is moving in the direction of rationalization of care and standardization of practices, with, for example, recommendations from the High Authority of Health (HAS) on ADHD at the end of 2014, or on autism since 2005 , or reports commissioned from major research institutions (such as those of INSERM: in 2004 on the evaluation of psychotherapies and in 2005 on conduct disorders). This logic of standardization, which reconfigures the authority between professionals in the psychotherapeutic world, is difficult to reconfigure with a psychoanalytical practice that emphasizes the singularity of cases, and more generally with the realm of meaning and values of the psychoanalytical community (Fansten, 2006).

These few reminders of recent mental health history are not intended to objectify a decline in psychoanalysis, which is both obvious, if we compare its current situation with that of France in the 1970s, but also extremely complex to describe in detail over a more recent period. This is especially so since the decline of psychoanalysis is an old and recurrent theme ${ }^{10}$, and is very particular in France compared to the situation in other countries (Fansten, 2018). Psychoanalysis remains a very prevalent theoretical reference in the field of contemporary French mental health, particularly in medical-psychological centers (CMP), which are essential elements of the territorial network organized by the logic of the psychiatric sector. But today even these places, marked by the historical importance of psychoanalysis, are traversed by multiple tensions (Roos-Weil, 2016) that we see at work in daily practices and collaboration.

The study of the "wars of the subject" (Ehrenberg, 2004) at the level of ordinary psychiatric practices, rather than at the level of positions of justification adopted in the public sphere, allows us to stand back from binary oppositions, between meaning

9 Diagnostic and Statistical Manual of Mental Disorders, now the reference manual for classifying mental disorders, published by the American Psychiatric Association.

10 In the early 200os, the crisis state of psychoanalysis, both generally and internationally, was on the agenda of many psychoanalytical institutions. It was one of the priorities of the "Future Strategies of the IPA" (International Psychoanalytical Association), then chaired by Daniel Widlöcher of France, for the years 2003 to 2005. The American Psychoanalytical Association (APsaA) was sufficiently alarmed by the crisis to commission a "Marketing Strategy Report on the Image of Psychoanalysis in the United States", in August 2002.

11 The expression "wars of the subject" refers to all the "passionate" quarrels and controversies between different conceptions of psychological life. 
and action, for example (Borelle, 2015). Similarly, in this article our intention is not to rule on the outcome of this controversy, but rather to examine that outcome from a sociological perspective, as it is experienced by the actors themselves, focusing in particular on the current impression of the defenders of psychoanalysis that they are losing the battle. Our objective is to understand the basis of this sense of crisis and the related defensive discourses, and what they produce in daily practices with children considered to be agitated.

\section{Sociology, allied or threatening?}

To do so, we first propose a reflexive detour by analyzing the progress of our surveys at various health centers that receive children who may be qualified as agitated. The history of the investigation, the way in which fields have opened or closed, and in which collaboration, mistrust or hostilities have been organized, is largely understood by each other's positions and imaginary in the context and due to the sense of crisis that we have just described. Our first negotiations were difficult, especially in a first center, even though we had a personal contact there. We encountered a major closure of the field following the presentation of our subject, in which we highlighted the diagnosis of ADHD as one of the qualifications of the behaviors studied. This medical-psychopedagogical center (CMPP), in which psychoanalytic reference was central, welcomed us, but discussions between professionals quickly led to reluctance to respond favorably to our request, for various reasons. The main one was that the introduction of the term hyperactivity, even if the idea was to denaturalize it, would bring a notion into the minds of caregivers that they literally did not want to hear about.

By contrast, in several other centers also rooted in a psychodynamic approach, the entry through agitation, which we put forward more, following these first difficult negotiations, allowed the establishment of a fairly rapid relationship of trust. This was the case in the places mentioned above: the day hospital located in the south of Paris, the mental health center and the CMP in northern France. This was also the case in institutions with approaches and care methods similar to those centers, including a CATTP and a CMP also located in the southern districts of Paris, as well as a mental health center located in the northern districts ${ }^{12}$. While access to the field was generally obtained quickly with an agreement on entry by way of agitation (again perceived by professionals as a symptom and not a disorder), some of the CMP staff who were fervent advocates of psychoanalysis expressed reluctance and questioned the very existence of agitation as a symptom. These professionals wanted to stay clear of the survey, which made it very difficult to carry out the field work at this center.

Note that initially our wish to diversify the places of investigation by also contacting institutions and services where the dominant approach was not psychodynamic met with more or less explicit mistrust. In a CMP using other approaches, our proposal for collaboration was eventually rejected. The stated reason was a lack of time, but according to one of the staff members who was also working in another center that we surveyed, the real reason was more likely that the other institutions we were surveying at the time were dominated essentially by the psychoanalytical approach, and that this may have aroused fears of an investigation against their practices.

Finally, once they were working in the different fields, sociologists were sometimes asked to participate in collaboration that went beyond the scope of the research. These requests might traditionally be based on a logic of return, with the hope that the sociologist's external viewpoint could produce more knowledge and nourish the reflexivity of professionals towards their own practices. This type of reasoning was particularly sought after at a time marked by a feeling of crisis likely to give rise to doubt. For example, one of the directors of a CMP in the northern districts of Paris told the sociologist: "What I'd like is for you to help us understand what we're doing." But proposals for collaboration sometimes went even further, such as in the southern districts of Paris, where a researcher was invited to participate

12 Note that the reception of the survey varied from one institution to another, and that the cluster in question grouped together different institutions. 
in a day organized by a mental health network on the theme of taking disability into account in professional practices, as well as a study day on collective care practices in the context of institutional psychotherapy, a symposium on the psychopathology of behavioral disorders in children and adolescents, and finally a project to create a prevention structure in mental health, between the health, social and school sectors. In the latter case, discussions with one of the child psychiatrists focused directly, among other subjects, on the possible alliance between social sciences and psychoanalysis, with the idea of opposing the alliance between behaviorist approaches and neuroscience.

These reactions, however different they may be, must all be understood in a context where the defenders of psychoanalysis are precisely on the defensive, ready to imagine alliances that could participate in their re-legitimization, and suspicious of collaborations or simply interactions that could further weaken them, internally or externally.

Aside from the potential but actually rare collaborations with the social sciences, the institutions in which we conducted our surveys are required to work with various partners. In the context we have described, and taking into account the rather defensive stance adopted by many of the professionals we met, these partnerships take various forms and must overcome significant obstacles that we will now highlight.

\section{The challenge of working in partnership}

The injunction to work in partnership is now strong in many areas and mental health is no exception. Irrespective of their theoretical approaches and daily practices, health centers must collaborate with other actors who are also dealing with the children they receive. When it comes to agitated children or behavioral disorders, schools are an essential partner in a wide range of situations, firstly because they are very often the source of the request for care, and secondly because they expect medical teams to provide feedback, particularly when it comes to sharing information that can be sensitive from a medical point of view. The notion of a "shared secret" is indeed interpreted in different ways and many care-givers consider that the sharing in question can only be between health professionals and not with professionals in the educational or social fields. Very often, the school's request is first interpreted and decoded by the health care teams to know how to reformulate it, how to respond indirectly to it, so that it is beneficial first for the child, and secondarily if possible for the school institution.

Take for example the case of Nicolas, discussed during a synthesis meeting in a day hospital located in the northern districts of Paris, in order to prepare a meeting at school. The child was described as very agitated at school, to the extent that "the teacher can't take it anymore". Very violent comments were reportedly made, since the school principal allegedly told Nicolas' mother one day that "the school is not intended to accommodate animals". A child psychiatrist at the day hospital then wondered about Nicolas' teacher who complained all the time about him yet wanted him to repeat the year. She described this teacher as depressed, even deeply depressed. The psychiatrist considered the teacher's attitude towards Nicolas to be problematic because variable, alternating between phases of rejection or aggressiveness and phases of "love" or "fusion". Health professionals planned to "calm down the school and the teacher" by saying "that at the sector level, work is getting stronger". On the other hand, they did not want to say that a therapeutic process had just been set up, because "it is none of their business". The child psychiatrist then explained that she did not want them to "harass" her to find out what happened in the care sessions, which were protected by medical confidentiality. In such cases, the school is seen as getting a raw deal, due to the material conditions in which children must be taught and managed, due to certain individuals who are not doing well or do not behave in a child-friendly way, and finally due also to a system that is generally out of breath or too rigid. As with parents, partnership cannot be established on an equal footing because the educational institution is considered partly responsible for the difficulties encountered. The information that passes from one place to another is therefore selected and evaluated according to the effects it may have on the child, via the reaction of National Education professionals. 
In other cases, partnership with the school is difficult to establish because the division of roles between professionals and institutions is not shared by all. For instance, during an informal meeting at the school attended by care-givers from the day hospital located in the southern districts of Paris, staff from the child's school (the principal, the teacher, the school assistant) and the child's parents, the care-givers were very annoyed by the attitude of the school staff, who took advantage of the meeting to make the mother talk about her difficulties, which caused her to pour out her feelings and to burst out crying. They came out of the meeting in a fury against the principal, the teacher and the teacher, not because the mother should not have been told about her relationship with her son in this way, but because it was not the right place to do so. The mother was to be received some time later in the day hospital where she could express herself again, this time to the great satisfaction of the caregivers. Caregivers believe that everyone should stay in their place and that the school professionals are neither competent nor in the right setting to make parents talk about their personal problems. This results in misunderstandings that are difficult to resolve.

Similar tensions, although based on different issues, can also arise with social workers (Turlais, 2016). When a child's situation requires recourse to social services for a report or the possible implementation of an educational measure, discussions between caregivers and social workers may stumble over the time frame of the actions to be implemented (the social emergency may clash with a slow process that is necessary, according to the caregivers, for therapy), or even the nature of the necessary interventions (while protective measures are an important element of the arsenal of social workers, caregivers often consider them as a last resort). In many cases a psychoanalytical frame of reference may be shared by the various actors involved, even if social workers may use it mainly to give psychological depth to the actions they recommend (by easily using terms such as "transfer", "framework" or "action" to describe the behavior of young people and their own (re)actions), while psychotherapists may make it their main working tool, paying more attention to the precision of the terms used, in a register of analysis rather than action. The field survey conducted in northern France also showed that the problem of the boundary between psychiatry and social work is a problem for psychiatry professionals themselves, and that this raises crucial issues of the concrete division of labor and the sharing of responsibility between social work and psychiatry (Borelle, 2017).

The articulation of professional practices is also an issue within health institutions themselves, since children can be monitored, simultaneously or successively, by different services. It is not uncommon for children to arrive in services where the dominant reference is psychoanalysis, even though they are treated by professionals using very distant reference frameworks. This is the case of nine-year-old Sofiane, whose file was discussed in a synthesis meeting at a CMP located in northern France. The child psychiatrist who presented the situation stated that, until then, the child had been treated by a "very cognitive neuro-pediatrician" who had diagnosed ADHD and had started a methylphenidate treatment. But at the follow-up appointment after one month of treatment, the same neuro-pediatrician considered that the child also needed psycho-educational follow-up. The child psychiatrist commented as follows:

So who does this? I don't know... He prescribes it to increase the effectiveness of the treatment, so the thing is completely reversed! We see the opposite, so we have difficulty understanding each other. He sees attention deficit disorder first and then inhibition as a side effect of treatment that requires psychological support. So we get parents back after that... And we necessarily feel used! We're called in to support the treatment. Obviously Quasym acts on the symptom, not on the anxiety component.

In such situations, the articulation between health professionals is done at a distance, especially if both of them immediately believe that a common ground will be very difficult to find. Professionals inspired by psychoanalysis can tolerate a drug treatment that they obviously would not have prescribed if they think that, in the medium term, their action will decide parents to stop the treatment and to 
focus more on the psychotherapy. In other cases, professionals from different backgrounds may find a compromise between practices that are not necessarily contradictory once implemented, even if they are interpreted differently by each party. For example, regular interviews with parents can be described by some as an accompaniment to psychotherapy, and by others as a step in a parental guidance process.

The structures located in the northern districts of Paris are those that, among our different fields, offer the most examples of bricolages that make it possible to compromise between different approaches, without the professionals giving up a primarily psychodynamic orientation. Practices as different as psychotherapies and more body-centered approaches (shiatsu, psychomotor or occupational therapy) can be combined, just as interpretive work based on psychoanalysis does not exclude the occasional use of standardized child assessment tools.

In other areas, this type of bricolage is less explicit, less institutionalized, but can be implemented at the initiative of a particular professional, without necessarily explaining her or his way of doing things in a synthesis meeting. For example, here is what Émilie, a child psychiatrist from the CMP in northern France, said during an informal discussion with us:

Previously, when faced with parents who call on a graphic therapist, I'd have said: "We don't focus on the symptom. We let the child live. We see what he can say about it. We don't put on labels, we don't put people in boxes. We don't have an instrumental approach. I wasn't trained in that." But now I'm not the purist as I used to be. I think that we must respond to the request of parents who expect this. Society's evolving, one has to work together.

The child psychiatrist introduces here the last form taken by the partnership challenge, which consists in working with parents (Béliard; Eideliman, 2018) on the basis of articulation, no longer between different professional practices, but rather between practices rooted in different types of expertise: one formalized, the other experiential (Borkman, 1976). With a view to promoting a "therapeutic alliance" with parents, the psychiatrist says she is prepared to use standardized tools, not so much for diagnostic purposes as to answer those who ask for more accounts about the professional activity in this center.

It seems more objective, the parents are at the center, they participate. In addition, it allows you to have written results. Otherwise, few written reports are given to the CMP. Often, it only confirms what we felt, but it is an affordance for the therapeutic alliance.

It is not because she adheres to other ways of doing things that Emilie agrees to leave the framework in which she was trained, but because of the need to adapt to social demand and also for strategic reasons, with the idea that this greater flexibility could allow families to become more involved in care. The psychoanalysts who work in these centers often feel "at odds" with the political and social developments in the health field, particularly on the question of the time frame raised by a psychologist working in the same CMP as Emilie:

And then there's the demand from parents, we're in a society of immediacy. And we're swimming against the tide. Sometimes things come out after a while. [...] If a child isn't fixed within two months, the treatment is discontinued!

This notion of "counter-current" work seems to us to be emblematic of a widespread feeling among these professionals, of being overtaken by a set of social evolutions that are more in line with what cognitive-behavioral approaches propose: treat parents as partners, provide solutions whose effectiveness can quickly be measured, make diagnoses in line with the dominant categories of contemporary psychiatry, calm children as well as the school, social workers and families, normalize behaviors in order to ease tensions, etc. Not everyone adopts the same attitude towards this feeling: some agree to hybridize their practices in order not to lose any chance of attracting a sufficiently large public to care, while others refuse these compromises at the risk of being further marginalized, but in a posture experienced as resistance. 


\section{References}

ABBOTT, A. The system of professions: an essay on the division of expert labor. Chicago: University of Chicago, 1988.

AKRICH, M.; MEADEL, C. De l'interaction à l'engagement : les collectifs électroniques, nouveaux militants de la santé. Hermès, La Revue, Paris, v. 47, n. 1, p. 145-153, 2007.

BÉLIARD, A.; EIDELIMAN, J.-S. Familles et professionnels dans le domaine de la santé mentale. In: COUTANT, I.; WANG, S. (Org.). Santé mentale et souffrance psychique : un objet pour les sciences sociales. Paris: CNRS Éditions, 2018. p. 289-306.

BORELLE, C. La place de l'expertise psychiatrique dans l'évaluation du handicap psychique : le cas de l'autisme. L'Information Psychiatrique, Paris, v. 9o, n. 4, p. 259-266, 2014.

BORELLE, C. Le traitement de la subjectivité comme opérateur micro-politique : le cas des enfants diagnostiqués autistes. Sciences Sociales et Santé, Paris, v. 33, n. 3, p. 43-64, 2015.

BORELLE, C. C'est uniquement social : sur la production d'un dualisme social/psychiatrique en sciences sociales et dans le travail ordinaire de la psychiatrie. Politix, Paris, v. 30, n. 117, p. 201-222, 2017.

BORKMAN, T. Experiential knowledge: a concept for the analysis of self-help groups. Social Service Review, Chicago, v. 5o, n. 3, p. 445-456, 1976.

CANCEIL, O. et al. Psychothérapie : trois approches évaluées. Paris: Inserm, 2004.

CASTEL, R. De la dangerosité au risque. Actes de la Recherche en Sciences Sociales, Paris, n. 47-48, p. 119-27, 1983.

CHAMAK, B. Les associations de parents d'enfants autistes : de nouvelles orientations. Médecine/Sciences, Montrouge, v. 24, n. 8-9, p. 768-77o, 2008.

CHAPIREAU, F. Quel handicap psychique peuton mesurer? L'Information Psychiatrique, Paris, v. 9o, n. 4, p. 243-246, 2014.
COUTANT I. Troubles en psychiatrie : enquête dans une unité pour adolescents. Paris: La Dispute, 2012.

CROSSLEY, N. Changement culturel et mobilisation des patients : le champ de la contestation psychiatrique au Royaume-Uni, 1970-200o. Politix, Paris, v. 73, n. 1, p. 23-55, 2006.

DEMAILLY, L.; GARNOUSSI, N. (Org.). Aller mieux : approches sociologiques. Lille: Presses Universitaires du Septentrion, 2017.

DEMAZEUX, S. Qu'est-ce que le DSM ? Genèse et transformations de la bible américaine de la psychiatrie. Paris: Ithaque, 2013.

DOBRY, M. Sociologie des crises politiques. Paris: Presses de la FNSP, 1986.

DODIER, N.; RABEHARISOA, V. Les

transformations croisées du monde «psy » et des discours du social. Politix, Paris, v. 19, n. 73, p. 9-22, 2006.

EHRENBERG, A. Le sujet cérébral. Esprit, Paris, v. 11, n. 309, p. 130-155, 2004.

FANSTEN, M. Le divan insoumis : la formation du psychanalyste : enjeux et idéologies. Paris: Hermann, 2006.

FANSTEN, M. Psychanalyse : une exception française. In: COUTANT, I.; WANG, S. (Org.). Santé mentale et souffrance psychique. Paris: CNRS Editions, 2018. p. 246-265.

FARRUGIA, F. La crise du lien social : essai de sociologie critique Paris: L’Harmattan, 1993.

HENCKES, N. La psychiatrie de secteur, quelle histoire, quel avenir? Esprit, Paris, v. 3, n. 413, p. 28-40, 2015 .

HUGHES, E. Le Regard sociologique : essais choisis. Paris: Editions de l'EHESS, 1996.

LE MOIGNE, P. L'efficacité thérapeutique : la psychopathologie, de l'expérimentalisme à l'évaluation. In: CHAMPION, F. (Org.). Psychothérapie et société. Paris: Armand Colin, 2008. p. 215-235.

LÉZÉ, S. L'Autorité des psychanalystes. Paris: PUF, 2010. 
ROOS-WEIL, F. CMP infanto-juvéniles : modèles, contraintes, malaise et vitalité. L'Information Psychiatrique, Paris, v. 92, n. 7, p. 519-526, 2016.

ROSANVALLON, P. La crise de l'état-providence. Paris: Seuil, 1981.

STÉBÉ, R. La crise des banlieues. Paris: PUF, 1999.

TRICART, J.-P. Initiative privée et étatisation parallèle : le secteur dit de l'enfance inadaptée.

Revue Française de Sociologie, Paris, v. 22, n. 4, p. 575-607, 1981.
TURLAIS, A. Pratiques psychothérapeutiques et protection de l'enfant: la décision difficile d'engager un processus de séparation: approches plurielles du processus décisionnel au sein d'une unité de psychothérapie infantile. 2016. Tese (Doutorado em Ciêntcias da Educação) - Université Paris Nanterre, Nanterre, 2016.

VIDAL, F. Brainhood, anthropological figure of modernity. History of the Human Sciences, Thousand Oaks, v. 22, n. 1, p. 536, 2009.

\section{Authors' contribution}

All the authors contributed equally to this study.

Received: $11 / 30 / 2018$

Approved: 01/04/2019 